\title{
Impact of Poverty and Inequality on Economic Growth of Bangladesh
}

\author{
Sumaya Khatun, Shakil Mahmood Shaon, Md Nazmus Sadekin* \\ Department of Economics, Mawlana Bhashani Science and Technology University, Santosh, Tangail-1902, \\ Bangladesh. \\ * E-mail of the corresponding author: sadekin08@gmail.com
}

\begin{abstract}
The radiation of poverty in Bangladesh is one of the highest in the world and millions of people suffer from the anguish of poverty. The country's poverty rose to 29.5 percent as of June, 2020 due to Covid-19, which was 20.5 percent in the last fiscal year 2019. Moreover, inequality make bad the persistence of poverty. This study attempts to focus on the poverty trends, economic growth and inequality in Bangladesh. Poverty is a multi-faced problem in the developing world and it is much more complex in rural setting. This study is also focused on to decompose inequality and poverty by rural, urban and national level household. The study is based on the analysis of secondary data which have been collected from different sources. The incidence of poverty has decreased to 20.5 percent from 31.5 percent in 2010. From the study, it is evident that, the incidence of poverty is higher in rural areas than that of the urban areas. This study tries to find the relationship among poverty inequality and growth. This study analysis GINI Index for income, Gini coefficient of per capita income of different survey years. The analysis shows a clear picture of the trend of poverty and inequality in Bangladesh. Using the Household Income and Expenditure survey of different years. This study attempt to figure out the relationship between inequality and per capita income. This study focusses on some problems of poverty and inequality and also mention some policy to eradicate of poverty and inequality.
\end{abstract}

Keywords: Covid-19, Household Survey, Inequality, Per Capita Income, Poverty

DOI: $10.7176 / \mathrm{JESD} / 12-10-10$

Publication date:May $31^{\text {st }} 2021$

\section{INTRODUCTION}

Although having sustain economic growth over last couple years, income inequality and poverty become one the most challenges in facing the economy. As in many developing countries, poverty in Bangladesh has been an alarming social issue for a significant amount of time. Shortly after its independence, approximately $82 \%$ of the population lived under the poverty line. However, since economic reforms and trade liberalization of early 1990s, along with accelerated economic growth since early-2000s, Bangladesh has experienced a dramatic progress in reducing poverty (Lesso, 2015). Bangladesh's economic reform started with the implementation of investment friendly economic policies, privatization of public industries, budgetary discipline, and liberalization of trade were among the key elements behind acceleration of Bangladesh's economy. Since then, Bangladesh has been among the fastest growing economies in the world, exceeding 6 percent growth annually between 2004 and 2015. The GDP growth further accelerated exceeding 7 percent mark since then, and is projected to gradually exceed 10 percent growth until 2020.Among Bangladesh's many economic and social achievements, dramatic reduction in poverty in often considered a phenomenon among international organizations such as IMF and The World Bank. Between 1972 and 2018, Bangladesh's population living on less than $\$ 1.90 /$ day is estimated to have fallen from $90 \%$ to $9 \%$. Between 2008 and 2018 , the per capita income in the country increased $149 \%$.

As of 2020, female labor force participation rate stands at $45 \%$, while net female school enrollment rate stands at a staggering 98\%.World Economic Forum ranks Bangladesh as the most gender-equal nation in South Asia (ranked 47th, followed by Maldives 106th; India 108th) (Lesso, 2015).

The objectives of this research to identify the problems of poverty and inequality, and to what are the main reason behind of them. To know how developing countries like Bangladesh can overcome this problem and can achieve the sustainable economic growth. However, the precise research objectives of the study are as follows: 
To identify the problems of poverty and inequality.

To identify some policy/measures to solve the problems of poverty and inequality.

To identify the present situations of poverty and inequality of Bangladesh.

\section{LITERATURE REVIEW}

Breuning and Majeed (2020) have highlighted a negative impact of inequality on economic growth in their recent research. They re-evaluate this hypothesis focusing on both inequality and poverty and their interaction. They replicate previous results showing that inequality has a negative impact on growth. However, they show that when we account for both inequality and poverty, the negative effect of inequality on growth appears to be concentrated amongst countries with high poverty. This would argue for policies targeted towards alleviating poverty rather than policies about redistribution (Breunig \& Majeed, 2020).

Chowdhury \& Hossain (2019) have tried to find the relationship among poverty inequality and growth. They also try to connect the Karl Marx's thoughts on functional income distribution and inequality in capitalism. Using the Household Income and Expenditure Survey of 2010 and 2016 they attempt to figure out the relationship among them. The incidence of poverty in Bangladesh is one of topmost in this globe; about $25 \%$ of the population is living under poverty lines and $12.3 \%$ of its population is living under the extreme poverty line. They find poverty has reduced significantly from 2000 to 2016 , which is more than $100 \%$ but in recent time poverty reduction has slowed down. Despite the accelerating economic growth, the income inequality also increasing where the rate of urban inequality exceeds the rural income inequality. Slower and unequal household consumption growth makes sloth the rate of poverty reduction. Average annual consumption fell from 1.8\% to 1.4\% from 2010 to 2016 and poorer households experienced slower consumption growth compared to richer households(Chowdhury \& Hossain, 2019).

Islam (1970) assessed long term relationship between inequality and growth in Bangladesh with a methodology of Kuznets pattern inverted U hypothesis first introduced by Simon Kuznets since 1955. The popular concept of Kuznets hypothesis suggests that as economic growth occurs, income inequality first increase and then decline after a certain turning point. The study of Kuznets hypothesis is popular to the international economic environment rather than domestic, especially to the developing countries where the per capita GDP is below the level of world average. He found the evidence that the presumption of Kuznets hypothesis has satisfied in the economy of Bangladesh in national level. In low income countries, structural adjustment is necessary to satisfy the Kuznets hypothesis(Islam, 1970).

Jones and Novak (2012) have indicated consequences of poverty and inequality and the challenge they pose to the engaged social work academic and practitioner. They argued that, especially for a profession with a claimed commitment to values based on equality, social justice and meeting human need, poverty impose a requirement on social workers to speak out and not to collude with social policies that make the plight of the impoverished even harder and their lives even worse(Jones \& Novak, 2012).

Killick has set out the range of policy options available to national governments wishing to reduce income disparities. He has shown a distinction between static and dynamic redistribution (called progressive growth). The former, essentially a zero-sum endeavor, involves transfers of existing income and/or wealth from the rich to the poor, whereas progressive growth requires only that increments to income and wealth accrue to the poor in proportions which reduce inequalities over time. First, however, it must consider why policy interventions may be desirable in the first place (Killick, 2002).

Matin (2017) has also analyzed the long term relationship between growth and inequality in Bangladesh. Following the seminal work of Simon Kuznets (1955), the causal relationship running from growth to inequality has been characterized as an inverted U-relationship, where inequality first rises with growth and subsequently falls as a 
country becomes richer. The per capita real income had significant positive effect and income squared had significant negative effect on Gini coefficient. As per their findings Bangladesh has made considerable progress in the field of literacy, nutrition and reproductive health care but all have the essence of inequality. The increasing growth was accompanied by rising inequality over the period under consideration. Bangladesh's main challenge is now reducing income inequality. Disparity of income is both a virtue and a vice. The virtue of providing rewards for effort and generating economic growth must be balanced against the vice of inequality's manifest injustice. Beginning with July 2015 Bangladesh has been classified as a LMIC by the World Bank (Matin, 2017).

Mcknight (2019) has reviewed the theoretical literature and empirical evidence on the relationship between poverty, inequality and economic growth. He found evidence that economic inequality is good for growth as well as new convincing evidence that inequality is bad for growth. Variation in data quality, methodologies, the range of countries included in different studies makes it difficult to compare the evidence. A recent hypothesis that the relationship between inequality and growth might be non-linear, with very low and very high levels of inequality being harmful to growth but a range in between where the relationship is not clearly defined might provide a means to unify some of the conflicting findings (Mcknight, 2019).

White and Anderson (2001) proposes three possible definitions, based on comparing the poor's share in incremental income with their existing share, their population share and an international norm, and examines the pattern of growth over time and in different regions. The growth of the poor's income can be decomposed into a growth effect and a distribution effect. Using data from 143 growth episodes it is found that the growth effect dominates, but that distribution is important in a significant minority of cases. In over a quarter of cases distribution played a stronger role than growth in increasing the income for the poor. Moreover, if there is no systematic relationship between growth and distribution, then it is clearly better to have growth that is pro-poor rather than not in order to achieve international poverty reduction targets. However, it is not associated with progressive changes in distribution. Moreover, modeling the determinants of the poor's share in incremental income finds a robust perverse relationship with governance - less liberty leads to a more pro-poor pattern of growth.

\section{METHODOLOGY}

I have used all the secondary data from Wikipedia, online article, journal, Newspaper, Various types of survey, economic review like financial express in this study. I have also used secondary data from Household Income and Expenditure Survey (HIES) of Bangladesh. These are the secondary source of data conducted by the Bangladesh Bureau of Statistics (BBS). I also used different data sources like World Bank Data Bank, IMF, Bangladesh Bank, Ministry of Finance and so on. In addition, various statistical report, for example, book and different published articles were reviewed to write the paper. Different statistical techniques, graph, chart, line chart, bar diagram used to analyze this data.

\section{FINDINGS AND RESULT ANALYSIS}

\section{POVERTY SITUATIONS OF BANGLADESH}

Poverty alleviation is one of the major indications of the socio-economic development of a state and society. According to SDG's Bangladesh progress report -2018 the poverty rate is 21.8 percent in 2018 whereas it was 56.7 percent in 1991. The government has set up a target to reduce the poverty to 18.6 percent at the end of the $7^{\text {th }}$ five years plan (2016-2016). Though Bangladesh is ahead of many developing countries in poverty alleviations, still approximately one-fifth portion of total population of the country lives below the poverty line. According to Human development index 2018, Bangladesh's position was 136 among 189 countries. In 2016, Bangladesh was 139 in the list.

\section{TRENDS OF POVERTY:}

The latest HIES was conducted in 2016, According to the result of this survey, poverty trends in Bangladesh describes below: 
Within half an era the incidence of income poverty (measured by CBN considering the upper poverty line) declined almost 7 percent points (from 31.5 in 2010 to 24.3 in 2016). During this period the compound poverty reduced per year 4.23 percent. On the contrary, the rate of income poverty declined from 40.0 percent to 31.5 percent from 2005 to 2010 . At the time compound poverty annually reduced by 4.67 percent. In urban areas poverty reduction rate is higher (4.68\%) than rural areas (1.97\%). During 2010 to 2016, the decreasing rate of the depth of the poverty (measured by poverty gap) was 4.28 percent. The trends of poverty are depicted in table 1 .

Table 1: Trends of Poverty in Bangladesh.

\begin{tabular}{|c|c|c|c|c|c|}
\hline & 2016 & 2010 & $\begin{array}{c}\text { Trend of income poverty } \\
\text { Annual change (\%) (2010- } \\
\text { 2016) }\end{array}$ & 2005 & $\begin{array}{c}\text { Annual change (\%) (2005- } \\
\text { 2010) }\end{array}$ \\
\hline Head Count Index & \multicolumn{5}{|l|}{} \\
\hline National & 24.3 & 31.5 & -1.23 & 40 & -4.67 \\
\hline Urban & 18.9 & 21.3 & -1.68 & 28.4 & -5.59 \\
\hline Rural & 26.4 & 35.2 & -1.97 & 43.8 & -4.28 \\
\hline Poverty Gap & 5 & 6.5 & -4.28 & 12.8 & -6.3 \\
\hline National & 5.9 & 4.3 & -1.61 & 9.1 & -7.93 \\
\hline Urban & 3.9 & -5.12 & 13.7 & -5.46 \\
\hline Rural & 5.4 & 7.4 & \multicolumn{5}{|l}{} \\
\hline Squared Poverty Gap & 1.5 & 2 & -4.68 & 4.6 & -8.81 \\
\hline National & 1.5 & 1.3 & -1.33 & 3.3 & -8.64 \\
\hline Urban & 1.2 & -4.21 & 4.9 & -8.75 \\
\hline Rural & 1.7 & 2.2 &
\end{tabular}

Source: BBS, HIES-2016.

\section{POVERTY VERSUS EXTREME POVERTY}

Bangladesh has been suffering in extreme poverty in last few decades. Bangladesh has achieved impressive progress to mitigate poverty in the last decade and the government of Bangladesh has taken numerous steps to fight against poverty. The poverty rate for Bangladesh in 2016 was $24.3 \%$ that is about $101 \%$ less than the year of 2000 and the extreme poverty rate for 2016 was $12.9 \%$ that's is $165 \%$ lower than 2000 . The international extreme poverty rate was 13.8 percent (18.5\% in 2010) in the same year, which is higher than Bangladesh extreme poverty rate. Between 2010 and 2016poverty fell significantly but this rate has slowed down in recent years. Poverty fell faster rate in rural areas than in urban areas and rural poverty rates declined from 35.2 to 26.4 percent, while urban poverty rates decreased from 21.3 to 18.9 percent. The pace of economic growth is outstanding since 2010 with a GDP growth rate on average 6.8\% per year between the periods of 2010 to 2018. Despite the high, the rate of poverty reduction is comparatively slow, which in the indication of the unequal distribution of income. Unequal household consumption growth of Bangladesh is the main cause of slower rate of poverty reduction. Accelerating economic growth could not able to reduce poverty at time same pace.

In its December 18, 2019 report, Bangladesh Bureau of Statistics (BBS) claimed that the overall poverty rate dropped1.3 per cent to 20.5 per cent in the Fiscal Year 2018-19 compared to the preceding FY while the extreme poverty rate dropped to 10.5 per cent from the preceding FY's 11.3 per cent. BBS officials claimed that these estimates were based on economic growth rate and its impact on the state of poverty in the country.

After reading the report, I tried to relate the 8.15 per cent GDP growth to 1.3 per cent poverty reduction but failed to demystify BBS's claims. I am wondering how the BSS statisticians assessed the impact of growth on poverty level in the country. Obviously, these are guesstimates which are subjective statistics, and depend largely on 
statisticians' regression (forecasting) models and may or may not have much factual bearing with reality on the ground.

Table 2: Poverty versus extreme poverty in Bangladesh.

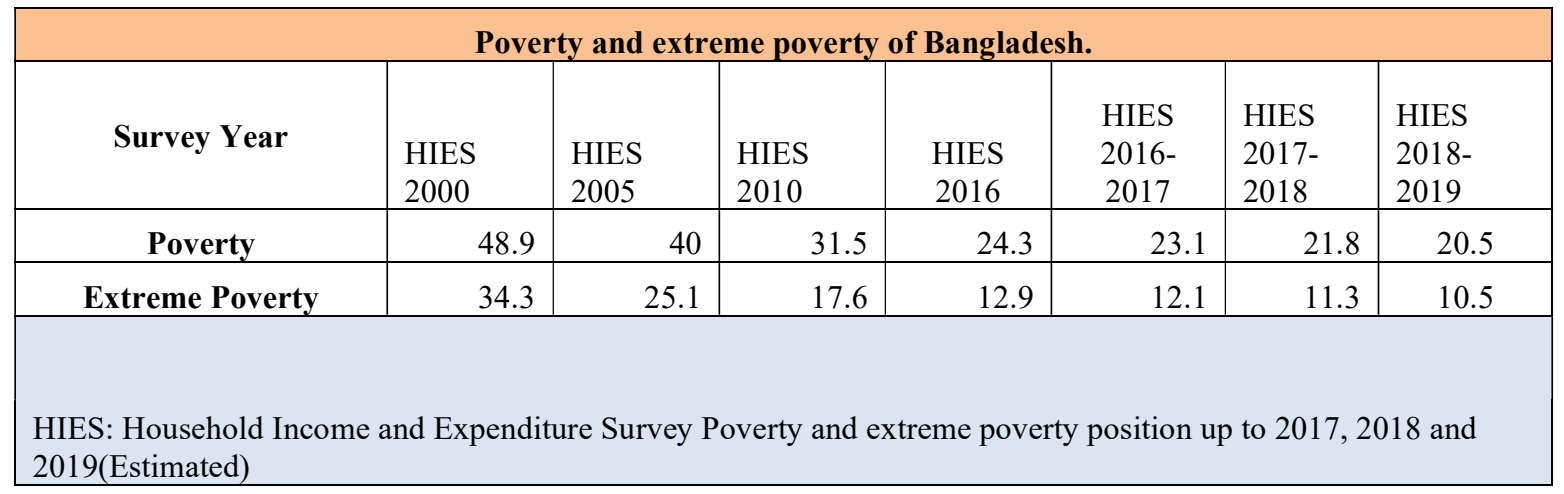

Table 3: Poverty and extreme poverty position, Source: HIES 2016.

Poverty and extreme poverty position, 2017, 2018 and 2019

\begin{tabular}{|c|c|c|c|c|c|c|c|c|c|c|}
\hline & $2009-10$ & $2010-11$ & 2011-12 & $2012-13$ & $2013-14$ & $2014-15$ & $2015-16$ & \begin{tabular}{|l|}
$2016-17$ \\
\end{tabular} & $2017-18$ & $2018-19$ \\
\hline GDP growth rate & 5.57 & 6.46 & 6.52 & 6.01 & 6.06 & 6.55 & 7.11 & 7.28 & 7.86 & 8.15 \\
\hline Per capita real GDP (taka) & 41,076 & 43,190 & 45,421 & 47,491 & 49,701 & 52,243 & 55,259 & 58,603 & 62,477 & 66,795 \\
\hline $\begin{array}{l}\text { Growth rate per capita } \\
\text { real GDP }\end{array}$ & 4.14 & 5.15 & 5.17 & 4.56 & 4.65 & 5.12 & 5.77 & 6.05 & 6.61 & 6.91 \\
\hline Poverty & 31.5 & & & & & & 24.3 & 23.1 & 21.8 & 20.5 \\
\hline Extreme poverty & 17.6 & & & & & & 12.9 & 12.1 & 11.3 & 10.5 \\
\hline
\end{tabular}

\section{Graph 1: Comparison of poverty and extreme poverty of Bangladesh.}

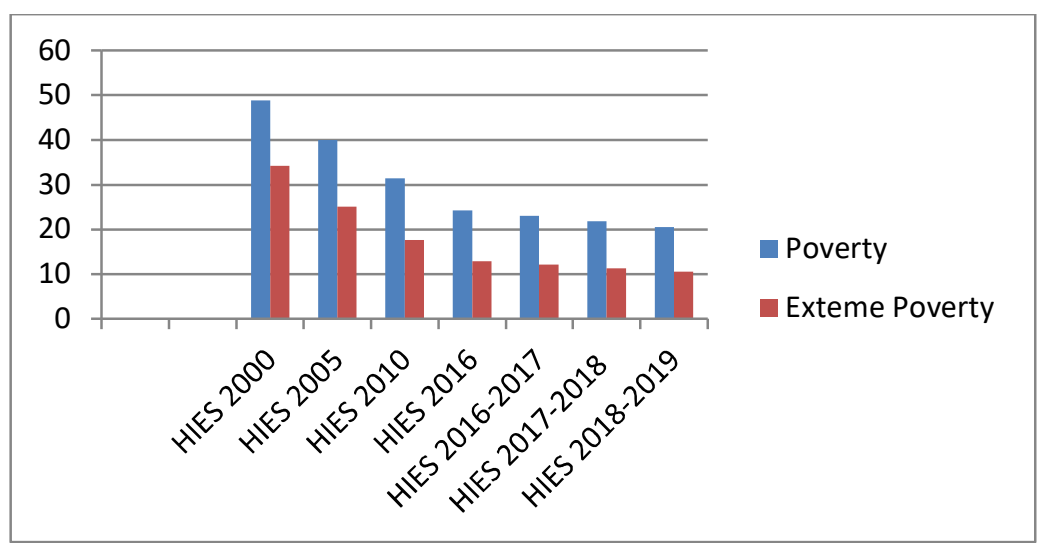

\section{HOUSEHOLD INCOME, EXPENDITURE AND CONSUMPTIONS}

The statistics of household nominal income, expenditure consumption from the surveys 2005 to 2016 have been given on table 4 . 
Table 4: Monthly household nominal income, expenditure and consumption expenditure by residence.

\begin{tabular}{|c|c|c|c|c|}
\hline \multirow{2}{*}{ Year of Survey } & \multirow{2}{*}{ Residence } & \multicolumn{3}{|c|}{ Average monthly (Taka) } \\
\cline { 3 - 5 } & Income & Expenditure & $\begin{array}{c}\text { Consumption } \\
\text { expenditure }\end{array}$ \\
\hline \multirow{3}{*}{2016} & National & 15945 & 15715 & 15430 \\
\cline { 2 - 5 } & Rural & 13353 & 14156 & 13868 \\
\cline { 2 - 5 } & Urban & 22565 & 19697 & 19383 \\
\hline \multirow{3}{*}{2010} & National & 11479 & 11200 & 11003 \\
\cline { 2 - 5 } & Rural & 9648 & 9612 & 9436 \\
\cline { 2 - 5 } & Urban & 16475 & 15531 & 15276 \\
\hline \multirow{3}{*}{2005} & National & 7203 & 6134 & 5964 \\
\cline { 2 - 5 } & Rural & 6096 & 5319 & 5165 \\
\cline { 2 - 5 } & Urban & 10463 & 8533 & 8313 \\
\hline
\end{tabular}

Source: BBS, HIES-2016.

\section{POVERTY ESTIMATES: NATIONAL AND SUBNATIONAL LEVELS}

The poverty lines reported here are the "upper" poverty lines, i.e., the poverty lines that give a more generous allowance for nonfood items compared to the so-called "lower" poverty lines. Head count ratios are given for the nation as a whole and for specific geographical areas of the country.

\section{Head Count Ratio at the National Level}

Poverty Headcount Ratio at National Poverty Lines: \% of Population data was reported at $24.300 \%$ in 2016 . This records a decrease from the previous number of $31.500 \%$ for 2010. Bangladesh's BD: Poverty Headcount Ratio at National Poverty Lines: \% of Population data is updated yearly, averaging 35.750 \% from Dec 2000 to 2016 , with 4 observations. The data reached an all-time high of $48.900 \%$ in 2000 and a record low of $24.300 \%$ in 2016 . Bangladesh's BD: Poverty Headcount Ratio at National Poverty Lines: \% of Population data remains active status in CEIC and is reported by World Bank. The data is categorized under Global Database's Bangladesh - Table BD. World Bank. WDI: Poverty. National poverty headcount ratio is the percentage of the population living below the national poverty lines. National estimates are based on population-weighted subgroup estimates from household surveys; World Bank, Global Poverty Working Group. Data are compiled from official government sources or are computed by World Bank staff using national (i.e. country-specific) poverty lines; This series only includes estimates that to the best of our knowledge are reasonably comparable over time for a country. Due to differences in estimation methodologies and poverty lines, estimates should not be compared across countries.

\begin{tabular}{ccccccc} 
Last & Previous & Min & Max & Unit & Frequency & Range \\
$\boldsymbol{\nabla} 24.300$ & $\boldsymbol{\nabla} 31.500$ & 24.300 & 48.900 & $\%$ & Yearly & $2000-2016$ \\
2016 & 2010 & 2016 & 2000 & & & \\
\hline
\end{tabular}

\section{Source: World Bank}

Head Count Ratio (HCR) on the basis of CBN method in 8 divisions The headcount ratio of incidence of poverty in eight administrative divisions using CBN method is described in table 5 . 
Table 5: Division wise incidence of poverty (HCR) by CBN method (In percentage)

\begin{tabular}{|c|c|c|c|c|c|c|}
\hline \multirow{2}{*}{ Divisions } & \multicolumn{5}{|c|}{2016} & \multicolumn{3}{c|}{2010} \\
\cline { 2 - 7 } & Total & Rural & Urban & Average & Rural & Urban \\
\hline Dhaka & 16 & 19.2 & 12.5 & 30.5 & 38.8 & 18 \\
\hline Sylhet & 16.2 & 15.6 & 19.5 & 28.1 & 30.5 & 15 \\
\hline Chattogram & 18.4 & 19.4 & 15.9 & 26.2 & 81 & 11.8 \\
\hline Barishal & 26.5 & 25.7 & 30.4 & 39.4 & 39.2 & 39.9 \\
\hline Khulna & 27.5 & 27.3 & 28.3 & 32.1 & 31 & 35.8 \\
\hline Rajshahi & 28.9 & 30.6 & 22.5 & 29.8 & 30 & 29 \\
\hline Mymensing & 32.8 & 32.9 & 32 & & & \\
\hline Rangpur & 47.2 & 48.2 & 41.5 & 42.3 & 44.5 & 27.9 \\
\hline & & & Using the lower poverty line & \\
\hline Dhaka & 7.2 & 10.7 & 3.3 & 15.6 & 23.5 & 3.8 \\
\hline Sylhet & 8.7 & 9.6 & 6.5 & 13.1 & 16.2 & 4 \\
\hline Chattogram & 11.5 & 11.8 & 9.5 & 20.7 & 23.5 & 5.5 \\
\hline Barishal & 12.4 & 13.1 & 10 & 15.4 & 15.2 & 16.4 \\
\hline Khulna & 14.2 & 15.2 & 10.7 & 21.6 & 22.7 & 15.6 \\
\hline Rajshahi & 14.5 & 14.9 & 12.2 & 26.7 & 27.3 & 24.2 \\
\hline Mymensing & 17.6 & 18.3 & 13.8 & & & \\
\hline Rangpur & 30.5 & 31.3 & 26.3 & 27.7 & 29.4 & 17.2 \\
\hline
\end{tabular}

Source: BBS, HIES-2016

From above table we can see that Rangpur division has the highest incidence of poverty at 47.2 percent. On the other hand, Dhaka division has the lowest incidence of poverty at 16.0 percent. The reduction rate is almost half. In Barisal, Khulna and Sylhet division, poverty rate is higher in urban areas than rural areas. Urban poverty in Sylhet and Chattogram division increased in 2016 though the average poverty rate decreased compare to 2010 .

\section{GINI INDEX FOR INCOME}

GINI coefficient or GINI index has been used to measure the income inequality and it has risen significantly last few decades throughout the world. The value of GINI coefficient varies from 0 to 1,0 meaning there is no inequality (perfect equality) and 1 indicates perfect inequality where income is highly skewed to an individual (possess all the income). The values of GINI coefficient were higher to urban areas from 2000 to 2016 compared to rural areas, which indicates that income inequality higher in an urban area than rural areas. The data shows that income equality has been rising in Bangladesh over the period.

The Gini coefficient is measured on a scale of 0 to 1 ; the closer it is to 1 the higher the inequality is in the society. 
Graph 2: Trend of income inequality of Bangladesh.

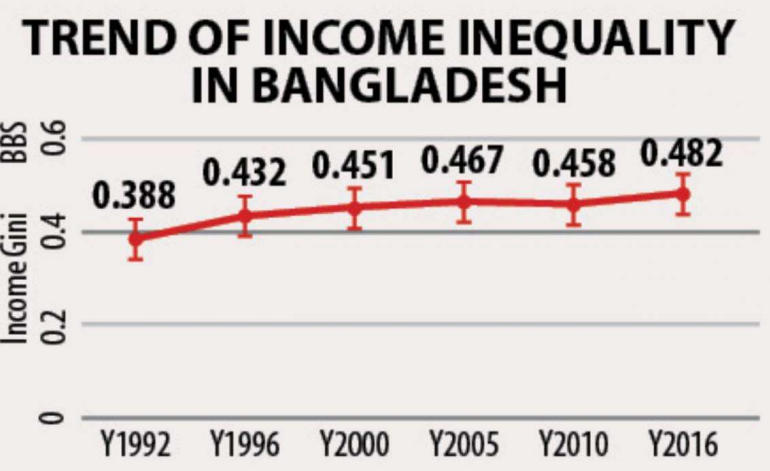

Figure source: The daily star (2019, May 19)

Table 6: GINI index for income:

\begin{tabular}{|c|c|c|c|c|c|c|c|c|c|c|c|c|c|}
\hline \multicolumn{14}{|c|}{ Gini Index for Income } \\
\hline Year & 1973 & 1981 & 1983 & 1985 & 1988 & 1991 & 1995 & 2000 & 2005 & 2010 & 2016 & $\begin{array}{l}\text { Change } \\
\text { during } \\
1973- \\
2016\end{array}$ & $\begin{array}{c}\text { Average } \\
\text { annual } \\
\text { rate of } \\
\text { change }\end{array}$ \\
\hline National & 0.36 & 0.39 & 0.36 & 0.38 & 0.38 & 0.39 & 0.43 & 0.45 & 0.47 & 0.46 & 0.48 & 0.12 & 0.76 \\
\hline Rural & 0.35 & 0.36 & 0.35 & 0.36 & 0.37 & 0.36 & 0.38 & 0.39 & 0.43 & 0.43 & 0.44 & 0.09 & 0.62 \\
\hline Urban & 0.38 & 0.41 & 0.37 & 0.37 & 0.38 & 0.4 & 0.44 & 0.5 & 0.5 & 0.45 & 0.43 & 0.05 & 0.5 \\
\hline
\end{tabular}

Source: World Bank,Tradingeconomics.com.

Graph 3: Comparison of Gini index for income among national, urban and rural area:

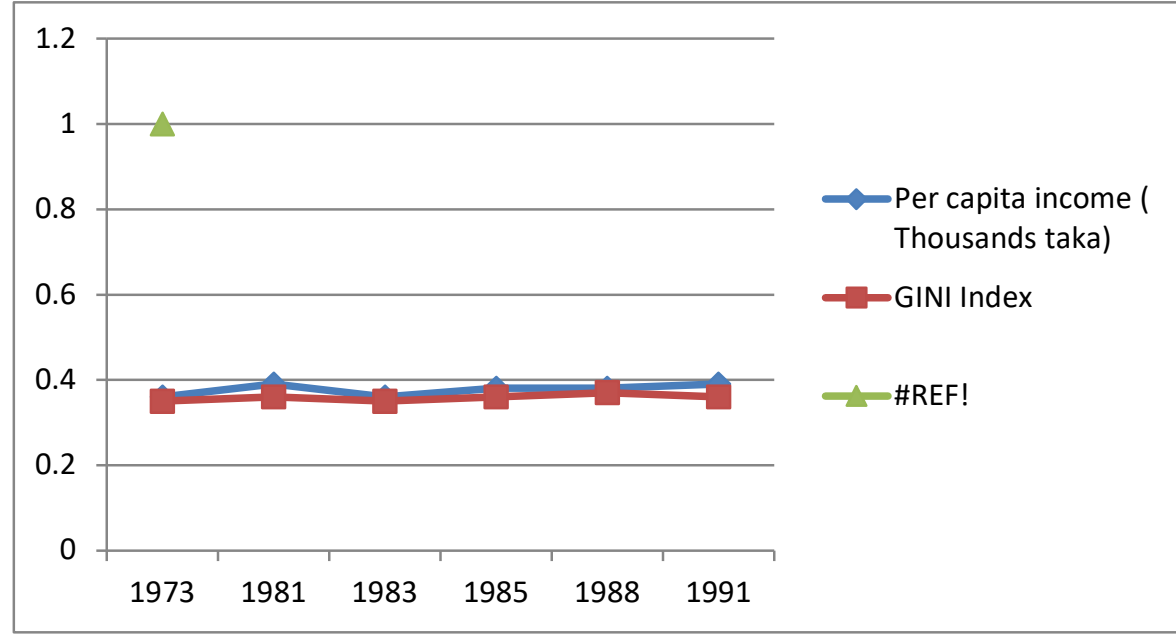




\section{GINI COEFFICIENT OF PER CAPITA INCOME:}

When we consider GINI Coefficient on per capita income for the periods of 2000 to 2016, we observed the similar results that we obtained for household income. We observed that from the below diagram that rural income inequality has increased over the periods but there was a fall in urban income inequality between the periods of 2005 to 2010 and then it increased.

The Gini coefficient is measured on a scale of 0 to 1 ; the closer it is to 1 the higher the inequality is in the society.

\section{Table 7: GINI Coefficient of Per Capita Income:}

\begin{tabular}{|c|c|c|c|c|c|c|}
\hline \multicolumn{7}{|c|}{ Gini Index of per capita income . } \\
\hline Year & 2000 & 2005 & 2010 & 2016 & $\begin{array}{c}\text { Change } \\
\text { during } \\
2000- \\
2016\end{array}$ & $\begin{array}{c}\text { Average } \\
\text { annual } \\
\text { rate of } \\
\text { change } \\
\%\end{array}$ \\
\hline National & 0.45 & 0.47 & 0.46 & 0.48 & 0.01 & 0.16 \\
\hline Rural & 0.39 & 0.43 & 0.43 & 0.44 & 0.03 & 0.98 \\
\hline Urban & 0.5 & 0.5 & 0.45 & 0.46 & 0.04 & -0.91 \\
\hline Source: Wor
\end{tabular}

Source: World Bank, Tradingeconomics.com.

\section{Graph 4: Gini index of per capita income.}

Gini index of per capita income.

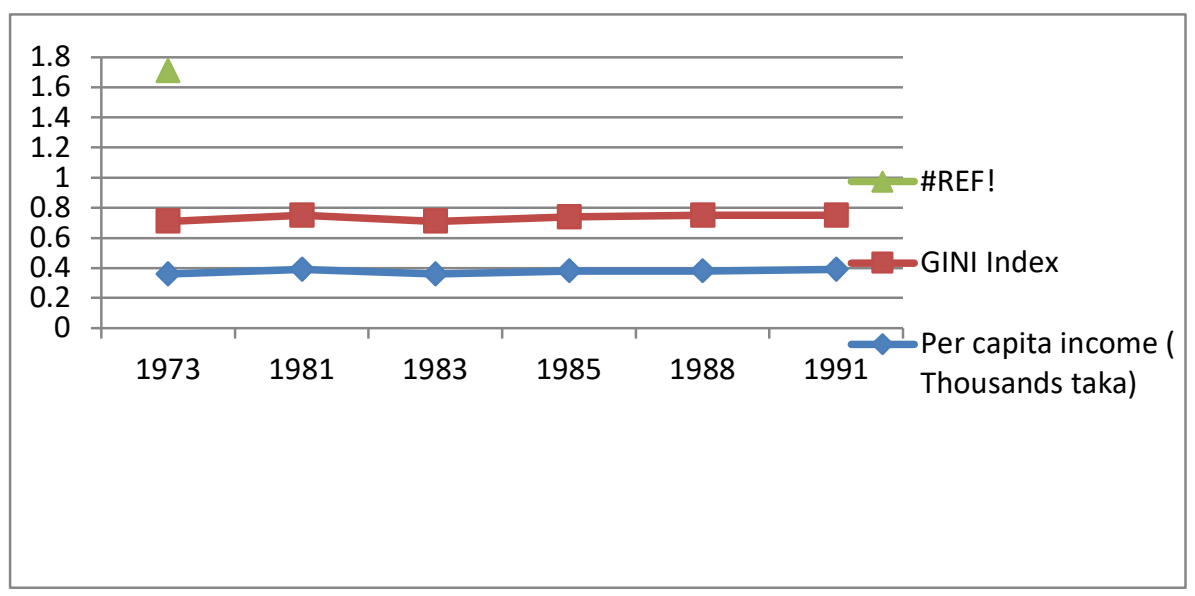




\section{RELATIONSHIP BETWEEN INEQUALITY AND PER CAPITA INCOME}

Simon Kuznets first observed the pattern distribution of income, he said in the early stage of development both growth and inequality shall go together. In Bangladesh, both per capita income and GINI coefficient increases is the same pace, which means growth accelerate income inequality in Bangladesh.

Table 7: Relationship between inequality and per capita:

\begin{tabular}{|c|c|c|c|c|c|c|c|c|c|c|c|c|}
\hline \multicolumn{10}{|c|}{ Relationship between inequality and per capita income. } \\
\hline Year & 1973 & 1981 & 1983 & 1985 & 1988 & 1991 & 1995 & 2000 & 2005 & 2010 & 2016 & $\begin{array}{c}\text { Per } \\
\text { thousand } \\
\text { taka }\end{array}$ \\
\hline $\begin{array}{l}\text { Per capita } \\
\text { income ( } \\
\text { Thousands } \\
\text { taka) }\end{array}$ & 0.36 & 0.39 & 0.36 & 0.38 & 0.38 & 0.39 & 0.43 & 0.45 & 0.47 & 0.46 & 0.48 & \\
\hline GINI Index & 0.35 & 0.36 & 0.35 & 0.36 & 0.37 & 0.36 & 0.38 & 0.39 & 0.43 & 0.43 & 0.44 & \\
\hline
\end{tabular}

\section{Graph 5: Relationship between inequality and per capita:}

Relationship between inequality and per capita income.

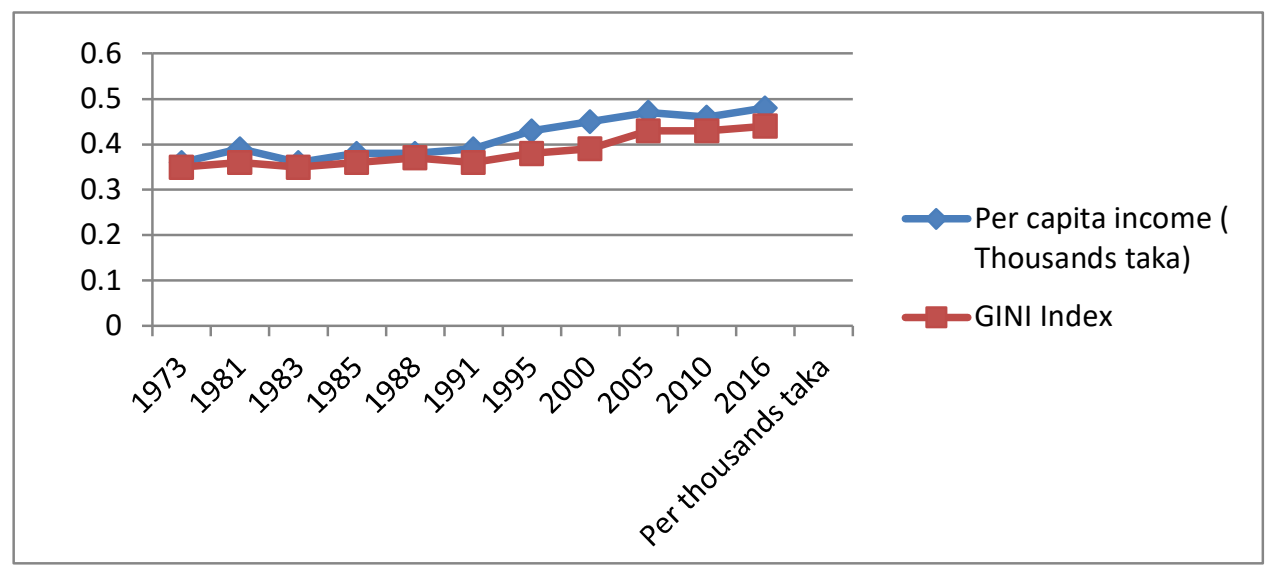




\section{Problems of Poverty and inequality}

Regardless of its causes, poverty has devastating consequences for the people who live in it. Poverty and inequality have very harmonious consequences on economic conditions and social lives of Bangladeshi peoples.

\section{Family Problems}

The poor are at greater risk for family problems, including divorce and domestic violence. A major reason for many of the problems families experience is stress. Families that are poor have more stress because of their poverty, and the ordinary stresses of family life become even more intense in poor families. The various kinds of family problems thus happen more commonly in poor families than in wealthier families. Compounding this situation, when these problems occur, poor families have fewer resources than wealthier families to deal with these problems.

\section{Health, Illness, and Medical Care}

The poor are also more likely to have many kinds of health problems, including infant mortality, earlier adulthood mortality, and mental illness, and they are also more likely to receive inadequate medical care. Poor children are more likely to have inadequate nutrition and, partly for this reason, to suffer health, behavioral, and cognitive problems.

\section{Education}

Poor children typically go to rundown schools with inadequate facilities where they receive inadequate schooling. They are much less likely than wealthier children to graduate from high school or to go to college. Their lack of education in turn restricts them and their own children to poverty, once again helping to ensure a vicious cycle of continuing poverty across generations.

\section{Housing and Homelessness}

The poor are, not surprisingly, more likely to be homeless than the non-poor but also more likely to live in dilapidated housing and unable to buy their own homes. Many poor families spend more than half their income on rent, and they tend to live in poor neighborhoods that lack job opportunities, good schools, and other features of modern life that wealthier people take for granted.

\section{Crime and Victimization}

Due to poverty and inequality the rate of crime of can be increased. This can create differences between the wealthier and the poor. Most of the more than 2 million people now in the nation's prisons and jails come from poor or near-poor backgrounds. Criminal behavior and criminal victimization, then, are other major consequences of poverty.

\section{POLICY OF POVERTY REDUCTIONS AND RECOMMENDATION TO AMELIORATE ECONOMIC GROWTH OF BANGLADESH}

\section{End all types of poverty from everywhere}

Government should emphasize on poverty reduction of all people and social protection benefits for people including the poor and the vulnerable. Need to ensure equal rights and access to economic and natural resources 
as well as to technology and financial resources. It also emphasizes on creating sound policy frameworks based on pro-poor and gender- sensitive development strategies for accelerated poverty reduction.

\section{End hunger, achieve food security and improved nutrition and promote sustainable agriculture}

To reduce poverty, we need to end hunger and malnutrition and ensure access to safe and nutritious food. This has to be achieved by doubling agricultural productivity and incomes of small-scale food producers (bottom 40 per cent farmers). Sustainable food production systems and resilient agricultural practices are a key factor in achieving this goal. Sustainable agricultural practices that protect biodiversity and genetic resources are essential for future food security. This will require increased investment in rural infrastructure, agricultural research and development, and extension services. While increased agricultural production will enhance food availability, improved food security will also require efficient food markets by reducing trade restrictions and the elimination of export subsidies and export measures with equivalent effects. Proper functioning of food commodity markets will also require access to market information to avoid excessive price fluctuation.

\section{Ensure healthy lives and promote well-being for all at all ages Introduction}

Need to ensure health and well-being for all at all ages by improving maternal and child health, ending the epidemics of major communicable diseases, reducing non-communicable and mental diseases and ensuring access to reproductive health- care services. These objectives will be achieved through realizing other objectives such as providing universal health coverage, ensuring access to safe, affordable and effective medicines and vaccines for all, supporting research and development of vaccines and medicines for communicable and non-communicable, substantially increasing health financing and developing health workforces in developing countries. In addition, the capacity of developing countries for early warning, risk reduction and management of national and global risks will need to be enhanced.

\section{Ensure equitable quality education and promote lifelong learning opportunities for all}

We should emphasizes attaining proficiency in primary and lower secondary education, ensuring access of both boys and girls to quality early childhood development and pre-primary education, ensuring access to quality technical, vocational and tertiary education and eliminating disparities in education and ensuring equal access to all levels of education and vocational training for the vulnerable population especially persons with disabilities, indigenous peoples and children in vulnerable situations.

\section{Achieve gender equality and empower all women and girls Introduction}

We should emphasize on equality and empowerment of all women and girls to reduce poverty and increase national growth. Women's human capabilities deal with women's and girl's access to healthcare, life expectancy, nutrition, reproductive health, education, information, training, and other services that enable women to achieve better health and educational outcomes.

\section{Promote sustained, inclusive and sustainable economic growth, full and productive employment and decent} work for all

Government should emphasize on improving economic growth. High economic growth will be achieved through increased diversification and continued technological upgrading and innovation that will be biased towards the labor-intensive sectors. More productive employment opportunities and a better work environment will be created for both men and women across all age groups and for the disabled in the formal sector. 


\section{Reduce inequality among countries}

Government should need to focus on reducing inequality its citizens. Sustainable Development Goal 10 calls for nations to increase the income of the bottom 40 per cent of the population by empowering and promoting social, economic and political inclusion of all people irrespective of sex, age, disability, race, class, ethnicity, religion. Government also should ensure equal opportunity for all people.

\section{Microfinance}

Microfinance is regarded as an important measure to reduce poverty and the government recognizes it as the most visible anti-poverty instrument. PRSP states that up scaling micro-credit (a service of microfinance) and enhancing its poverty impact will be an important factor in realizing the goals of accelerated poverty reduction. The government has implemented many credit programs targeted for extremely poor. The government promotes microfinance sector by setting up the Microcredit Regulatory Authority, which formalizes microfinance institutions by providing licenses. Palli Karma Shahayak Foundation (PKSF) was also created as a wholesale organization of microfinance.

\section{Promotion of Private Investment}

PRSP states that promotion of private investment is one of the measures to achieve rapid economic growth and following policies are proposed: providing appropriate fiscal incentives; arranging for freehold land; facilitating entrepreneurship development among women; facilitating technological upgrading and improving business support services.

\section{CONCLUSION}

The eradication of poverty and inequality are the primary goals for the sustainable development of any country. However, achieving a reduction in poverty and inequality is a fundamental challenge in Bangladesh but Bangladesh has achieved remarkable success to eradicate poverty and extreme poverty. Despite considerable trust on poverty alleviation in all plan documents since the independence of Bangladesh, a significant number of people are still living below the poverty line. Bangladesh is still a low income country with substantial poverty, inequality and deprivation. Most of the labor force is engaged in informal low productivity and low income jobs. The poor group of the population is severely disadvantaged in terms of ownership of assets and has inadequate access to institutional finance as well as to basic services including quality education, healthcare, water and sanitation. It is constitutional obligation of the government to provide a decent living standard for the citizens by alleviating poverty. However, as in many other countries, poverty on Bangladesh is still a serious concern. Although, the present government of Bangladesh is very much hopeful in achieving the target of Millennium Development Goals (MSGs) as well as the targets of Visino-2021 related to poverty and inequality. This report might be quite difficult to achieve the targets, if the government does not give top priorities on the issues outlined above.

\section{REFERENCES:}

Ahmed, F. (2004). Practices of poverty measurement and poverty profile of Bangladesh. ERD Working Paper Series, 54.

Breunig, R., \& Majeed, O. (2020). Inequality, poverty and economic growth. International Economics, 161, 8399. https://doi.org/10.1016/j.inteco.2019.11.005

Chowdhury, M. N. M., \& Hossain, M. M. (2019). Poverty, Income Inequality and Growth in Bangladesh: Revisited Karl-Marx. American Finance \& Banking Review, 4(2), 1-10. https://doi.org/10.46281/amfbr.v4i2.324

European Anti-Poverty Network (EAPN). (n.d.). Causes of poverty and inequality. 
Hanmer, L., \& Naschold, F. (2000). Attaining the international development targets: Will growth be enough? Development Policy Review, 18(1), 11-36. https://doi.org/10.1111/1467-7679.00098

Islam, S. (1970). Inequality and economic growth in Bangladesh-a diversified evidence on Kuznets pattern 'U' hypothesis. Journal of the Bangladesh Agricultural University, 7(1), 117-123. https://doi.org/10.3329/jbau.v7i1.4973

Jones, C., \& Novak, T. (2012). Poverty and inequality. Poverty and Inequality, 2003, 1-74. https://doi.org/10.4337/9781789903713.00016

Killick, T. (2002). Inequality Briefing. Odi, 2(2), 6. http://www.odi.org.uk/sites/odi.org.uk/files/odiassets/publications-opinion-files/3810.pdf

Lesso, M. (2015). Poverty in Bangladesh. In The Borgen Project. https://borgenproject.org/poverty-bangladesh/

Matin, K. A. (2017). Economic Growth and Inequality in Bangladesh. 1-36. https://beabd.org/site/images/pdf/new17/73.pdf

Mcknight, A. (2019). Poverty ( LIP) Understanding the relationship between poverty, inequality and growth : a review of existing evidence. July.

Of, G., \& People, T. H. E. (2011). Government of the People’'S Republic of Bangladesh. June, 2345.

Singapore -- Britannica Online Encyclopedia. (n.d.).

http://www.britannica.com.vlib.excelsior.edu/EBchecked/topic/545725/Singapore

Social inequality - Wikipedia. (n.d.).

White, H., \& Anderson, E. (2001). Growth versus distribution: Does the pattern of growth matter? Development Policy Review, 19(3), 267-289. https://doi.org/10.1111/1467-7679.00134. 